González-Prieto, A. 2018. Conservation of Nearctic Neotropical migrants: the coffee connection revisited. Avian Conservation and Ecology 13(1):19. https://doi.org/10.5751/ACE-01223-130119

Copyright (C) 2018 by the author(s). Published here under license by the Resilience Alliance.

Guest Editorial

\title{
Conservation of Nearctic Neotropical migrants: the coffee connection revisited
}

Ana María González-Prieto ${ }^{1,2}$

${ }^{1}$ Department of Biology, University of Saskatchewan, Saskatoon, Saskatchewan, Canada, ${ }^{2}$ SELVA: Investigación para la

Conservación en el Neotrópico, Bogotá, Colombia

\section{Conservation des oiseaux migrateurs néotropicaux du Néarctique : la relation avec le café réexaminée}

Key Words: conservation; habitat; Neotropical migrants; shade coffee

Populations of Nearctic-Neotropical migratory songbirds that overwinter in South America are declining at greater rates than those wintering elsewhere (NABCI 2012). Persistent population declines over the last 50 years in species that overwinter primarily in montane habitats in the Northern Andes of South America are associated with habitat loss and deterioration on the wintering grounds (Jones et al. 2004, González-Prieto et al. 2017, Kramer et al. 2018, Wilson et al. 2018). For instance, species of conservation concern such as the Cerulean Warbler (Setophaga cerulea), Canada Warbler (Cardellina canadensis), and Olivesided Flycatcher (Contopus cooperi) have a predominantly Andean wintering distribution and have experienced steep declines in their populations in recent decades (Sauer et al. 2017) (Fig. 1).

The tropical Andes represent an exclusive wintering region for several Neotropical migrants and are recognized for their elevated biological richness and high levels of endemism across a range of resident taxa. Yet, this region has lost more than $90 \%$ of its original vegetation cover (Henderson et al. 1991). The current extent and spatial pattern of habitat transformation observed in the Andes are the result of historic and ongoing anthropogenic processes (Etter et al. 2008). For example, in Colombia, land use changed from crop cultivation in the 16th century to a system dominated by grazing in modern times. The continuous expansion of cattle pastures since the mid-1800s has been one of the major drivers of long-lasting transformations of the Andean landscape (Etter et al. 2008). As result, the landscape at montane altitudes (1000-3500 $\mathrm{m}$ asl) is composed of a mosaic where exotic grasses and crops are the predominant vegetation cover, and the remaining montane forests are highly fragmented (Armenteras et al. 2003, Rodríguez-Eraso et al. 2013).

Unprecedented rates of loss of natural habitats used by Neotropical migrants have directed conservation efforts toward shade-grown coffee plantations, which are one of the few remaining "forested" areas in mid- to high-elevation mountain ranges in Latin America (Perfecto et al. 2005). The Colombian Andes, and the coffee growing region of northern South America, have experienced two key landscape-scale transformations associated with coffee production (Guhl-Corpas 2006). First, during the initial establishment of coffee plantations (1850-1970), natural forest was replaced by shade-grown coffee plantations where the native canopy was maintained or replaced, and the understory was replaced by coffee bushes (Moguel and Toledo 1999) (Fig. 1). From the 1970s to the present time, technological modifications transformed shade-grown coffee plantations into agroecosystems with lower structural and floristic diversity, where intensively managed plantations are grown in full sun (Perfecto et al. 1996, Rice 1999). This change to "sun coffee" arose to increase coffee production and in response to the spread of the devastating coffee rust (Hemileia vastatrix) disease in Latin America. By reducing shade through the removal of shade trees, conditions for the growth and dispersal of the fungus decreased. These dramatic transformations in the Andean landscape have no doubt played a role in the steep population declines of a number of Nearctic-Neotropical migratory birds that overwinter in the Andes of northern South America.

The conservation value of shade-grown coffee for Neotropical migrants in northern South America is related, in part, to its distribution. Ideal conditions for coffee production in Colombia are found in the Andean mountains between 1200 and $1800 \mathrm{~m}$, which overlaps with the elevation belt that holds the highest concentration of migratory landbird species in the country (DíazBohórquez et al. 2014). The importance of shade coffee plantations for conservation of Neotropical migratory birds is also related to the observations that shaded coffee plantations tend to have higher species richness and abundance than other agroecosystems (reviewed by Komar 2006), or species richness is comparable to natural ecosystems (Tejada-Cruz and Sutherland 2004). Some species found in shade coffee plantations are as abundant or more abundant in shade coffee plantations than in natural forest habitats (e.g., Canada Warbler, Cerulean Warbler, Blackburnian Warbler [Setophaga fusca], Tennessee Warbler [Oreothlypis peregrina], Ovenbird [Seiurus aurocapilla], Swainson's Thrush [Catharus ustulatus]) (Komar 2006, 
Fig. 1. (A-B) Shade-grown coffee plantations on the western slope of the East Andes of Colombia. (C) Cerulean Warbler (Setophaga cerulea) and (D) Canada Warbler (Cardellina canadensis) overwinter predominately in montane Andean forest and shade-grown coffee plantations, and have experienced steep declines in their populations in recent decades. Photos: Ana María González-Prieto.

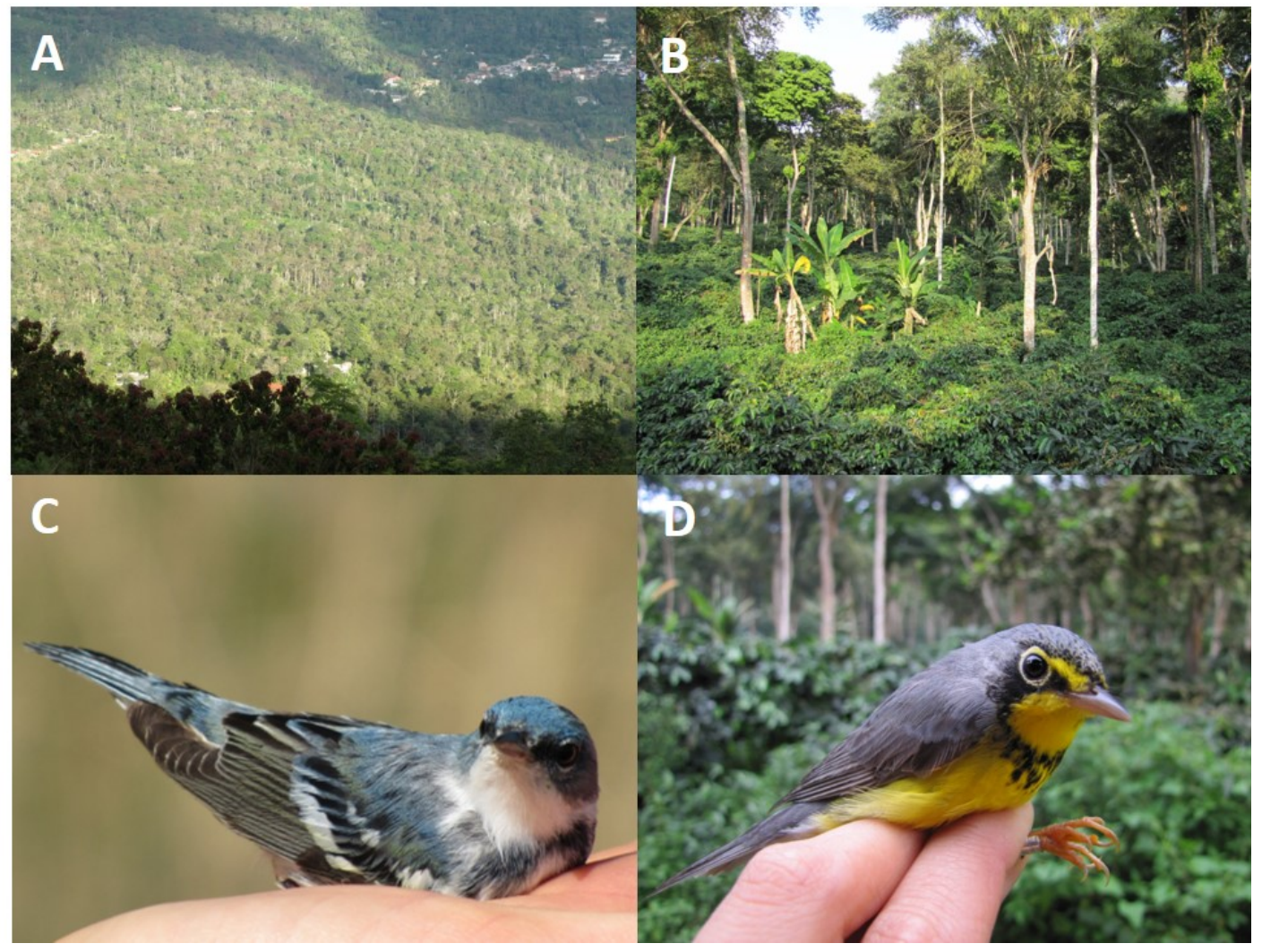

Bakermans et al. 2009, Gomez et al. 2013). Some species that overwinter in shade-grown coffee increase their daily and overwinter body condition, and have high overwinter survival and high between-season return rates (Bakermans et al. 2009, Colorado and Rodewald 2017).

Shade coffee production systems and terminology vary widely across Latin America from rustic or traditional systems where coffee is grown under the natural forest to technified shade systems where the forest is removed and replaced (Gobbi 2000). In Colombia, coffee is technically considered shade-grown when the density of any shade species is greater than 50 trees per hectare, and semishaded when the shade density is between 20 and 50 trees per hectare (Moreno 2007). The shade can be composed of a single species forming a single vertical stratum or by various species of, for example, leguminous nitrogen-fixing trees of the genera Inga, Albizzia, Leucaena, or Erythrina, which form a multistratum. As a strategy to diversify farmers' income, native (i.e., Cordia alliodora) or introduced (i.e., Pinus oocarpa or Eucalyptus grandis) species of commercial interest are also often used as shade (Farfán-Valencia 2007).

Shade-grown coffee supports high levels of biodiversity across different taxa from insects to mammals (Perfecto et al. 1996), and bird species richness often declines with agricultural intensification (Perfecto et al. 2003). Shade trees in coffee plantations provide important ecological services, including soil protection against erosion, replenishment of organic matter throughout leaf litter production, carbon sequestration, and perhaps most importantly for farmers, nitrogen fixation (Rice 1999, Soto-Pinto et al. 2009). This agroecosystem also provides habitat for native predators of coffee pests, including migratory birds, and for pollinators that contribute to higher coffee productivity and quality (Klein et al. 2003, Ricketts et al. 2004, Karp et al. 2013). Despite the value of the services provided by shade trees in coffee plantations, these traditional management practices are rapidly disappearing. In Colombia alone, sun coffee plantations increased from $36 \%$ in 1997 to $56 \%$ in 2013 , while shade-grown coffee decreased from $23 \%$ in 1997 to $10 \%$ in 2013 , with the steepest decline occurring between 2007 and 2013 (Escobar 2013).

Coffee drinkers can contribute to the conservation of surrogate habitats for wintering Neotropical migrants by becoming informed, choosing certified coffees that promote sustainable agricultural practices, and contributing to the growth of the shade coffee market by increasing demand. Coffee certification programs have three main categories that assign environmental, social, and/or economic value to coffee: shade-grown, organic, and fairtrade. Shade-grown certifications that contribute to the protection of winter habitat for migratory birds include Bird Friendly and Rainforest Alliance. The Bird Friendly certification 
was developed by the Smithsonian Migratory Bird Center and is based on decades of research aimed at understanding the habitat needs of birds and other wildlife in shade-grown coffee plantations. All Bird Friendly coffee is certified organic, and additional certification standards include a canopy height of 12 $\mathrm{m}$, a minimum $40 \%$ canopy cover measured during the dry season after pruning, and a complex floristic diversity and structure. The Rainforest Alliance certification promotes sustainable agriculture by protecting soils and water sources, reducing waste, and improving living conditions in coffee farms. To obtain certification, farms must maintain at least $15 \%$ of the native vegetation or a minimum canopy cover of $40 \%$ measured before pruning and during the rainy season when foliage is denser, and a minimum of 12 native species as shade in the coffee plantations, as well as comply with several infrastructural and management requirements (SAN2017). One of the current challenges of shadegrown certification programs to provide robust benefits for the conservation of winter habitat of Neotropical migrants is the mismatch between the certification at the farm scale and the scale at which desired conservation results are needed (Tscharntke et al. 2015). The limitations of dispersed certified farms for habitat conservation need to be considered by the certification programs, and landscape approaches are clearly needed (Tscharntke et al. 2015).

Coffee is the second-most traded commodity in the world, and its popularity has led to several innovations to meet rising demand. Changes in coffee systems to increase production have included the reduction or elimination of shade trees, the intense use of pesticides and synthetic fertilizers, and the development of new coffee varieties that allow for higher yields and resistance to sun and diseases (Arcila-Pulgarín 2007). For instance, broadspectrum organophosphate pesticides are widely sprayed on coffee bushes to control the coffee borer beetle (Hypothenemus hampei). In several regions of the Neotropics, fumigation overlaps with the overwintering period of migrant songbirds and/or with preparations for migration in spring (December to March). Such practices will affect the suitability of shade coffee plantations as overwinter habitat for Neotropical migrants by reducing insect availability if not by causing direct physiological effects on birds. Organic certified coffee assures consumers that several synthetic herbicides, pesticides, and fertilizers were not used during coffee production. In North America, the United States Department of Agriculture (USDA) organic certified coffee is produced under the standards established by the USDA National Organic Program, and the Canada organic certification standards are regulated by the Canadian Food Inspection Agency. Although complying with shade standards is not a requirement for this certification, by consuming organic coffee, we can support clean production systems that provided healthy ecosystems and healthy coffee. Fairtrade certification guarantees that coffee producers organized in cooperatives or associations receive a Fairtrade Premium and at least a minimum price per pound set by Fairtrade International to cover production costs and act as a safety net when market prices fall below sustainable levels. While organic and fairtrade certified producers may obtain some economic benefit from their certification status, their farms may not necessary protect as much biodiversity or provide quality winter habitat for migrants, in contrast to shade-certified farms (Philpott et al. 2007).
Rigorous and consistent assessment of the effect of certifications on the environment and on farmers' livelihood assets is scarce; however, certifications are more likely to generate more positive than negative impacts on ecological and economic sustainability (Bray and Neilson 2017, DeFries et al. 2017). Economic benefits for farmers might be more closely associated with enhanced yields, increased resilience, reduced dependence on agrochemicals, and increased access to credit than with price premiums or overall house income. Less quantifiable benefits may include improved farm and risk management, arguably better health and safety practices, improved local soil and water quality, and increased physical capital by investing certification premiums on farm equipment. Despite the incentives, certification costs such as modifying or implementing production, management, and administration systems to fulfill standards, and the cost of actually obtaining and maintaining certifications represent a barrier for some farmers since the financial gains may not be enough to outweigh the costs (Philpott et al. 2007). Smallholder farmers and laborers in rural areas in the tropics are one of the lowest income groups in the world (Cruz et al. 2015) and likely do not have access to the information on, or cannot afford the cost of, certification (DeFries et al. 2017). There is a clear need to develop mechanisms to ensure that low income farmers have the opportunity to benefit from participation in market-based conservation strategies (Gobbi 2000).

In optimal areas for coffee production where coffee is grown with and without shade, shade improves the physical aspects of the bean (e.g., color, size, density) and cup quality, which ultimately improves farmers' profits (Vaast et al. 2006). Incorporating robust technical support during shade-grown certification processes to improve coffee quality may provide economic incentives to produce shade-grown coffee while compensating the decrease in productivity associated with shade in several regions of Latin America. The price premiums of high coffee quality can surpass more than $100 \%$ of the market price of standard coffee quality (Vaast et al. 2006), and can reduce exposure and vulnerability to the devastating effects of low coffee prices on the landscape (i.e., replacement of shade coffee to cattle pastures) and on rural economies in Latin America (Bacon 2005).

Two species of coffee are commercially cultivated worldwide: Coffee arabica (Arabica) and Coffee canephora (Robusta). Arabica is the most widely consumed in the world and the principal variety grown throughout Latin America. Coffee production requires specific conditions of soil, temperature, and precipitation (Arcila-Pulgarín 2007). These conditions, along with socioeconomic factors, vary between and within countries and determine farming practices and the selection of coffee varieties that adjust to the production system. For instance, shade is required in regions of Colombia above $9^{\circ} \mathrm{N}$ where coffee is produced at lower altitudes and higher temperatures, and in Andean regions with bimodal precipitation patterns, extended soil moisture deficits, and high solar radiation intensity (ArcilaPulgarín 2007). It follows that shade-grown coffee certification standards are challenging or unrealistic to meet in many regions with heavy annual cloud cover, high rainfall, and high humidity without compromising yields. Indeed, in the Andean mountains of Colombia, sun coffee production has increased in those regions. In the central region of the Central Andes of Colombia, the production of sun coffee increased to $80 \%$ between 1997 and 
2013, while in drier and warmer regions at the northern extent of the Eastern Andes and along the Caribbean coast, the increase was only $15 \%$ during the same period (Escobar 2013). While increasing participation by setting lower standards is not optimal, more comprehensive market-based conservation strategies that facilitate their adoption and success in regions where sun coffee prevails are needed. For example, forest restoration and connecting corridors in regions that are less suitable for shade coffee might offer an alternative to farmers to engage in conservation of winter habitat for Neotropical migrants, while gaining benefits such as increased rates of pollination and resilience to pests (Ricketts et al. 2004, Imbach et al. 2017).

Despite the importance of shade-grown coffee plantations for overwintering or staging Neotropical migrant songbirds, this habitat clearly cannot replace native forest. Indeed, the conservation value of shaded coffee may be higher in areas of high deforestation and those lacking protected areas, where plantations may be the only forest-like habitat suitable for migrants (Perfecto et al. 1996, Bakermans et al. 2009). Neotropical migrants have been forced into this agroecosystem in response to the loss of natural habitat, and the quality of shade coffee plantations relative to the native forests from where they were carved is still to be fully addressed (but see Bakermans et al. 2009, Bayly et al. 2016). While conservation efforts to maintain shade coffee plantations are critical, efforts to restore or protect remaining forest are also needed.

Wide-reaching transformations in the Andean landscape and the rapid loss of shade-grown coffee plantations have surely contributed to the dramatic population declines of several Neotropical migrants. For instance, more than $60 \%$ of the Canada Warbler population has been lost over the last four decades (Sauer et al. 2017), more than $50 \%$ of its winter range is located within the Andes of Colombia, and land use changes in Andean winter grounds are likely the primary source of population decline (Wilson et al. 2018). In the face of this worrying situation, we can choose to be part of the solution for winter habitat loss for Neotropical migrants by informing other citizens and making ethical coffee choices. While novel evaluation criteria and procedures are urgently needed for the future success of certification programs (DeFries et al. 2017), certified shade-grown coffee gives us the option to reduce the social and environmental effects of our coffee consumption, and to directly contribute to the conservation of winter habitat for Neotropical migrants. Besides environmental benefits, the premium we pay can improve the living conditions of millions of farmers and laborers who are dependent on the coffee culture. A good start would be that passionate birders, researchers, and conservation biologists are consistent with the message we preach and make sure that our morning coffee was grown under shade.

Responses to this article can be read online at: http://www.ace-eco.org/issues/responses.php/1223

\section{Acknowledgments:}

I am thankful to the landowners of the farms where I conducted my $P h D$ research where I evaluated the relative quality of shade-grown coffee plantations versus native forest as winter habitat for
Neotropical migrants. Special thanks to the owners of Hacienda "La Fragua" and farms "Villa Gloria", "El Diamante", "Puerto López", "La Bonanza", and "El Quinini", in the East Cordillera of the Colombian Andes. I thank Rocio Espinoza and Fernando Farfán from Cenicafé for providing information about the current state of coffee production in Colombia, and to Jorge Botero and the "Comité de Cafeteros de Cundinamarca" for their logistic support during my research. I am grateful to my supervisor Keith A. Hobson for his ongoing support and for his invitation to write this guest editorial. I am also thankful to Nicholas J. Bayly for his timely comments on the last draft of this editorial.

\section{LITERATURE CITED}

Arcila-Pulgarín, J. 2007. Factores que determinan la productividad del cafetal. Pages 61-86 in H. F. Ospina and S. M. Marín, editors. Sistemas de producción de café en Colombia. Cenicafé, Chinchiná, Colombia.

Armenteras, D., F. Gast, and H. Villareal. 2003. Andean forest fragmentation and the representativeness of protected natural areas in the eastern Andes, Colombia. Biological Conservation 113:245-256. http://dx.doi.org/10.1016/S0006-3207(02)00359-2

Bacon, C. 2005. Confronting the coffee crisis: Can fair trade, organic, and specialty coffees reduce small-scale farmer vulnerability in northern Nicaragua? World Development 33:497-511. http://dx.doi.org/10.1016/j.worlddev.2004.10.002

Bakermans, M. H., A. C. Vitz, A. D. Rodewald, and C. G. Rengifo. 2009. Migratory songbird use of shade coffee in the Venezuelan Andes with implications for conservation of Cerulean Warbler. Biological Conservation 142:2476-2483. http://dx.doi.org/10.1016/ j.biocon.2009.05.018

Bayly, N. J., C. Gómez, K. A. Hobson, and K. V Rosenberg. 2016. Prioritizing tropical habitats for long-distance migratory songbirds: an assessment of habitat quality at a stopover site in Colombia. Avian Conservation and Ecology 11(2):5. http://dx.doi. org/10.5751/ACE-00873-110205

Bray, J. G., and J. Neilson. 2017. Reviewing the impacts of coffee certification programmes on smallholder livelihoods. International Journal of Biodiversity Science, Ecosystem Services \& Management 13:216-232. http://dx.doi.org/10.1080/21513732.2017.1316520

Colorado, G. J., and A. D. Rodewald. 2017. Patterns of change in body condition in wintering Neotropical-Nearctic migratory birds in shaded plantations in the Andes. Agroforestry Systems 91:1129-1137. http://dx.doi.org/10.1007/s10457-016-9989-9

Cruz, M., J. Foster, B. Quillin, and P. Schellekens. 2015. Ending extreme poverty and sharing prosperity: progress and policies. World Bank Group: Policy Research Note PRN/15/03. Development Economics, World Bank Group. [online] URL: https://openknowledge.worldbank.org/bitstream/handle/10986/23604/ Ending0extreme0rogress0and0policies.pdf?sequence $=1$

DeFries, R. S., J. Fanzo, P. Mondal, R. Remans, and S. A. Wood. 2017. Is voluntary certification of tropical agricultural commodities achieving sustainability goals for small-scale producers? A review of the evidence. Environmental Research Letters 12(3). http://dx.doi.org/10.1088/1748-9326/aa625e 
Díaz-Bohórquez, A. M., N. J. Bayly, J. E. Botero, and C. Gómez. 2014. Aves migratorias en agroecosistemas del norte de Latinoamérica, con énfasis en Colombia. Ornitologia Colombiana 14:3-27.

Escobar, D. 2013. Evolución de la caficultura en Colombia. La Misión del café, Universidad del Rosario. Bogotá, Colombia. [online] URL: http://www.urosario.edu.co/Mision-Cafetera/ Trabajos/

Etter, A., C. McAlpine, and H. Possingham. 2008. Historical patterns and drivers of landscape change in Colombia since 1500: a regionalized spatial approach. Annals of the Association of American Geographers 98:2-23. http://dx.doi.org/10.1080/00045600701733911

Farfán-Valencia, F. 2007. Producción de café en sistemas agroforestales. Pages 161-200 in H. F. Ospina and S. M. Marín, editors. Sistemas de producción de café en Colombia. Cenicafe, Chinchiná, Colombia.

Gobbi, J. A. 2000. Is biodiversity-friendly coffee financially viable? An analysis of five different coffee production systems in western El Salvador. Ecological Economics 33:267-281. http://dx. doi.org/10.1016/S0921-8009(99)00147-0

Gomez, C., N. J. Bayly, and K. V Rosenberg. 2013. Seasonal variation in stopover site use: Catharus thrushes and vireos in northern Colombia. Journal of Ornithology 154:107-117. http:// dx.doi.org/10.1007/s10336-012-0876-5

González-Prieto, A. M., N. J. Bayly, G. J. Colorado, and K. A. Hobson. 2017. Topography of the Andes Mountains shapes the wintering distribution of a migratory bird. Diversity and Distributions 23:118-129. http://dx.doi.org/10.1111/ddi.12515

Guhl-Corpas, A. 2006. La influencia del café en la evolución y consolidación del paisaje en las zonas cafeteras colombianas. Pages 191-206 in M. C. Cano, C. E. López, and D. M. Rodríguez, editors. Cambios ambientales en perspectiva histórica. Ecología histórica y cultural ambiental. Grupo gestión de cultura y educación ambiental. Facultad de ciencias ambientales. Universidad tecnológica de Pereira, Pereira, Colombia.

Henderson, A., S. P. Churchill, and J. L. Luteyn. 1991. Neotropical plant diversity. Nature 351:21-22. http://dx.doi. org/10.1038/351021e 0

Imbach, P., E. Fung, L. Hannah, C. E. Navarro-Racines, D. W. Roubik, T. H. Ricketts, C. A. Harvey, C. I. Donatti, P. Läderach, B. Locatelli, and P. R. Roehrdanz. 2017. Coupling of pollination services and coffee suitability under climate change. Proceedings of the National Academy of Sciences of the United States of America 114:10438-10442. http://dx.doi.org/10.1073/pnas.1617940114

Jones, J., J. J. Barg, T. S. Sillett, M. L. Veit, and R. J. Robertson. 2004. Minimum estimates of survival and population growth for Cerulean Warblers (Dendroica cerulea) breeding in Ontario, Canada. Auk 121:15-22. http://dx.doi.org/10.1642/0004-8038 (2004)121[0015:MEOSAP]2.0.CO;2

Karp, D. S., C. D. Mendenhall, R. F. Sandi, N. Chaumont, P. R. Ehrlich, E. A. Hadly, and G. C. Daily. 2013. Forest bolsters bird abundance, pest control and coffee yield. Ecology Letters 16:1339-1347. http://dx.doi.org/10.1111/ele.12173
Klein, A.-M., I. Steffan-Dewenter, and T. Tscharntke. 2003. Pollination of Coffea canephora in relation to local and regional agroforestry management. Journal of Applied Ecology 40:837-845. http://dx.doi.org/10.1046/j.1365-2664.2003.00847.x

Komar, O. 2006. Ecology and conservation of birds in coffee plantations: a critical review. Bird Conservation International 16:1-23. http://dx.doi.org/10.1017/S0959270906000074

Kramer, G. R., D. E. Andersen, D. A. Buehler, P. B. Wood, S. M. Peterson, J. A. Lehman, K. R. Aldinger, L. P. Bulluck, S. Harding, J. A. Jones, J. P. Loegering, C. Smalling, R. Vallender, and H. M. Streby. 2018. Population trends in Vermivora warblers are linked to strong migratory connectivity. Proceedings of the National Academy of Sciences of the United States of America 115:E3192E3200. http://dx.doi.org/10.1073/pnas.1718985115

Moguel, P., and V. M. Toledo. 1999. Biodiversity conservation in traditional coffee systems of Mexico. Conservation Biology 13:11-21. http://dx.doi.org/10.1046/j.1523-1739.1999.97153.x

Moreno, A. 2007. Fundamentos sobre sistemas de producción. Pages 15-20 in H. F. Ospina and S. M. Marín, editors. Sistemas de producción de café en Colombia. Cenicafé, Chinchiná, Colombia.

North American Bird Conservation Initiative Canada (NABCI). 2012. The state of Canada's birds, 2012. Environment and Climate Change Canada, Ottawa, Ontario, Canada. [online] URL: http:// www.stateofthebirds.org

Perfecto, I., A. Mas, T. Dietsch, and J. Vandermeer. 2003. Conservation of biodiversity in coffee agroecosystems: a tri-taxa comparison in southern Mexico. Biodiversity \& Conservation 12:1239-1252. http://dx.doi.org/10.1023/A:1023039921916

Perfecto, I., R. A. Rice, R. Greenberg, and M. E. der Voort. 1996. Shade coffee: a disappearing refuge for biodiversity. BioScience 46:598-608. http://dx.doi.org/10.2307/1312989

Perfecto, I., J. Vandermeer, A. Mas, and L. S. Pinto. 2005. Biodiversity, yield, and shade coffee certification. Ecological Economics 54:435-446. http://dx.doi.org/10.1016/j.ecolecon.2004.10.009

Philpott, S. M., P. Bichier, R. Rice, and R. Greenberg. 2007. Fieldtesting ecological and economic benefits of coffee certification programs. Conservation Biology 21:975-985. http://dx.doi. org/10.1111/j.1523-1739.2007.00728.x

Rice, R. A. 1999. A place unbecoming: the coffee farm of northern Latin America. Geographical Review 89:554-579. http://dx.doi. org/10.2307/216102

Ricketts, T. H., G. C. Daily, P. R. Ehrlich, and C. D. Michener. 2004. Economic value of tropical forest to coffee production. Proceedings of the National Academy of Sciences of the United States of America 101:12579-12582. http://dx.doi.org/10.1073/ pnas.0405147101

Rodríguez-Eraso, N., D. Armenteras-Pascual, and J. RetanaAlumbreros. 2013. Land use and land cover change in the Colombian Andes: dynamics and future scenarios. Journal of Land Use Science 8:154-174. http://dx.doi.org/10.1080/1747423X.2011.650228

Sauer, J. R., D. K. Niven, J. E. Hines, D. J. J. Ziolkowski, K. L. Pardieck, J. E. Fallon, and W. A. Link. 2017. North American 
breeding bird survey, results and analysis 1966 - 2015. Version 2.07.2017. Geological Survey, Patuxent Wildlife Research Center, Laurel, Maryland, USA. [online] URL: https://www.mbr-pwrc. usgs.gov/bbs/

Soto-Pinto, L., M. Anzueto, J. Mendoza, G. J. Ferrer, and B. de Jong. 2009. Carbon sequestration through agroforestry in indigenous communities of Chiapas, Mexico. Agroforestry Systems 78:39-51. http://dx.doi.org/10.1007/s10457-009-9247-5

Sustainable Agriculture Network (SAN). 2017. Sustainable agriculture standard. Version 1.2. [online] URL: https://www. sustainableagriculture.eco/blog/2017/11/9/is-saving-water-enough-5tss3

Tejada-Cruz, C., and W. J. Sutherland. 2004. Bird responses to shade coffee production. Animal Conservation 7:169-179. http:// dx.doi.org/10.1017/S1367943004001258

Tscharntke, T., J. C. Milder, G. Schroth, Y. Clough, F. Declerck, A. Waldron, R. Rice, and J. Ghazoul. 2015. Conserving biodiversity through certification of tropical agroforestry crops at local and landscape scales. Conservation Letters 8:14-23. http:// dx.doi.org/10.1111/conl.12110

Vaast, P., B. Bertrand, J. J. Perriot, B. Guyot, and M. Génard. 2006. Fruit thinning and shade improve bean characteristics and beverage quality of coffee (Coffea arabica L.) under optimal conditions. Journal of the Science of Food and Agriculture 86:197-204. http://dx.doi.org/10.1002/jsfa.2338

Wilson, S., J. F. Saracco, R. Krikun, D. T. T. Flockhart, C. Godwin, and K. R. Foster. 2018. Drivers of demographic decline across the annual cycle of a threatened migratory bird. Scientific Reports 8:7316. http://dx.doi.org/10.1038/s41598-018-25633-z 